\title{
Hyperkalaemic paralysis following traumatic rupture of the urinary bladder
}

\author{
HITOSHI SHINOTOH, TAKAMICHI HATTORI, KUNITAKA KITANO, JOJI SUZUKI \\ From the Department of Neurology, Matsudo Municipal Hospital, Matsudo City, Chiba, Japan
}

SUMMARY A case is reported of a 38-year-old man with hyperkalaemic paralysis following traumatic rupture of the urinary bladder.

Secondary hyperkalaemia is known to cause flaccid motor paralysis. The most frequent cause is renal insufficiency with anuria. ${ }^{1}$ The other causes include adrenal insufficiency, ${ }^{2}$ excessive intake of potassium salts $^{3}$ and injudicious use of spironolactone. ${ }^{4}$ In this paper we report an unusual case of rapidly developed flaccid quadriplegia following traumatic rupture of the urinary bladder.

\section{Case report}

A 38-year-old man was brought to the hospital in a state of flaccid quadriplegia. He had no history of previous neuromuscular disease. He had enjoyed good health until one evening a week before admission, when he drank a large amount of alcohol, quarrelled with someone and was beaten on his face, abdomen and back. He returned home by himself and slept for several hours. The next day when he got up, he found himself unable to move his legs. $\mathrm{He}$ had lower abdominal pain, passed a small amount of reddish urine and had no appetite. But he did not seek any medical advice and stayed at home for the next five days during which he only drank water. During this period there was some improvement in his weakness, so that he could manage to walk by himself. The night before admission he drank some alcohol and half an hour later his lower extremities became much weaker. He also noted some weakness of his upper extremities. The next morning when he woke up he found himself unable to move all four extremities.

In the emergency room, he was alert and conscious but very weak. He was dyspnoeic, could not move any limbs and complained of paraesthesiae in his hands and feet.

Address for reprint requests: Dr $\mathrm{H}$ Shinotoh, Department of Neurology, Brain Research Institute, School of Medicine, Chiba University, 1-8-1, Inohana-cho, Chiba City, Chiba 280, Japan.

Received 2 August 1983 and in revised form 2 October 1984. Accepted 29 October 1984
Examination revealed the axillary body temperature was $36.5^{\circ} \mathrm{C}$, pulse $60 / \mathrm{min}$ and irregular, blood pressure $84 /$ $54 \mathrm{mmHg}$ and respiration $22 / \mathrm{min}$. The chest was clear to percussion and auscultation. No heart murmur was audible. The abdomen was not distended but was slightly tender. He was completely tetraplegic with some neck muscloo involvement so that he could not raise his head from the bed. He had mild facial weakness. Deep tendon reflexee were absent. No sensory abnormality was noted. Trans urethral catheterisation yielded $2300 \mathrm{ml}$ of bloody urine if which many red blood cells were seen microscopicalls Laboratory data were as follows; ESR $6 \mathrm{~mm} / \mathrm{h}$; CRP $2+Q$ WBC $9400 / \mathrm{mm}^{3} ; \mathrm{RBC} 494 \times 10^{5} / \mathrm{mm}^{3} ; \mathrm{Hb} 15.3 \mathrm{~g} / \mathrm{d}$ Arterial blood taken with the patient breathing room a showed $\mathrm{pH} 7.221, \mathrm{pO}_{2} 16.3 \mathrm{kPa}$ and $\mathrm{pCO}_{2} 2.97 \mathrm{kP}$ Serum sodium $114 \mathrm{mmol} / \mathrm{l}$; serum potassium $8.7 \mathrm{mmol} /$; serum chloride $75 \mathrm{mmol} / \mathrm{l}$; serum calcium $0.85 \mathrm{mmol} / \mathrm{l}$; serum magnesium $1.07 \mathrm{mmol} / \mathrm{l}$; serum urea $25.2 \mathrm{mmol} / \mathrm{l}$; serum creatinine $1255 \mu \mathrm{mol} / \mathrm{l}$; CK $315 \mathrm{mU}$ (BB 2\%, MB $4 \%$, MM 92\%); serum myoglobin $160 \mathrm{ng} / \mathrm{ml}$; blood glucose $8.6 \mathrm{mmol} / \mathrm{l}$. Thyroid function and liver function tests were normal. ECG showed characteristic changes of hyperkalaemia with low $P$ wave, prolonged $P R$ interval, widened QRS complexes running into tall peaked $T$ wave.

He was given $250 \mathrm{ml}$ of $7 \% \mathrm{VW}$ sodium bicarbonate intravenously within a $\mathbf{3 0}$ minutes period, and at the end of this procedure he was able to raise his arms, respiration became easier and paraesthesiae dissapeared. $50 \mathrm{~g}$ of glucose and 10 units of soluble insulin were also given intravenously. Then he could move his legs. At this stage his serum sodium were $127 \mathrm{mmol} / \mathrm{l}$, serum potassium $5.7 \mathrm{mmol} / \mathrm{l}$, serum chloride $85 \mathrm{mmol} / \mathrm{l}$ and serum urea $25.7 \mathrm{mmol} / \mathrm{l}$. Hemodialysis was performed and after this procedure his serum electrolyte and urea became normal. On the third hospital day his muscle strength and his deep tendon reflexes were normal. A cystogram demonstrated a perforation of the dome of the bladder which was obstructed partially by the intestine or omentum and minor $N$ leakage of contrast material into the peritoneal cavity. On the fourth hospital day surgical repair was undertaken. He 
made an uneventful recovery and was discharged on the 14th hospital day.

Motor nerve conduction velocity of the right median nerve was studied three times during his admission. At the time of admission no muscle action potential was recorded. Three hours after admission when the patient was able to raise the arms, it was possible to obtain muscle action potentials. The motor nerve conduction velocity from elbow to wrist was $27 \mathrm{~m} / \mathrm{s}$ and the distal latency was $7 \cdot 2 \mathrm{~ms}$. On the third hospital day the motor nerve conduction velocity was $49 \mathrm{~m} / \mathrm{s}$ and the distal latency was $4.1 \mathrm{~ms}$.

\section{Discussion}

The clinical features presented suggested acute rhabdomyolysis precipitated by trauma, alcohol or both. This was the initial diagnosis. However a diagnosis of acute rhabdomyolysis was not likely because (1) muscle weakness was of ascending type and associated with paraesthesiae of hands and feet; (2) there was no muscle swelling or tenderness; (3) there was only mild elevation of CK and myoglobin and the urine was bloody; (4) muscle weakness improved rapidly with normalisation of serum potassium and ECG changes. Muscle weakness was thought, therefore, to be secondary to hyperkalaemia.

The mechanism of hyperkalaemia and uraemia in this case was thought to be by a "autodialysis feedback system" following traumatic rupture of the urinary bladder, ${ }^{5}$ in which the constituents of intraperitoneal urine are reabsorbed through the peritoneal surface. Beer contains much potassium, which might be one of the causes of rapidly developed hyperkalaemia. In this case the weakness of lower limbs improved spontaneously at first. On admission the rupture in the bladder was obstructed partially by the intestine or omentum which was demonstrated by the cystogram. The patient was able to urinate little by little at home, perhaps because of this spontaneous obstruction, so the serum potassium level may have decreased. But when he again consumed alcohol, the day before admission, the serum potassium level may have increased and tetraplegia developed rapidly.

The mechanism underlying the hyperkalaemic paralysis remains unknown. Muscle weakness has been attributed to myopathy, ${ }^{467}$ disturbances of neuromuscular junction ${ }^{8}$ or to neuropathy. ${ }^{9}$ There are few neurophysiological ${ }^{10} "$ or histopathological studies $^{1213}$ on this subject. Although this is the first description to the best of our knowledge, the transient slowing of motor nerve conduction velocity seen in our case suggests that there was a functional disturbance of peripheral nerve during hyperkalaemia.

\section{References}

' Finch CA, Sawyer CG, Flynn JM. Clinical syndrome of potassium intoxication. Am J Med 1946;1:337-62.

${ }^{2}$ Marks LJ, Feit E. Flaccid quadriplegia, hyperkalemia and Addison's disease. Arch Intern Med 1953;91:56-67.

${ }^{3}$ Bedford PD, Leeds MD. Acute potassium intoxication. Lancet 1954;2:268-70.

${ }^{4}$ Herman E, Rado J. Fatal hyperkalemic paralysis associated with spironolactone. Arch Neurol 1966;15:74-7.

s Ko KW, Randolph J, Fellers FX. Peritoneal self-dialysis following traumatic rupture of the bladder. $J$ Urol 1964;91:343-6.

- Livingstone IR, Cumming WJK. Hyperkalemic paralysis resembling Guillain-Barre syndrome. Lancet 1979; ii:963-4.

7 Bell H, Hayes WL, Vosburgh J, City K. Hyperkalemic paralysis due to adrenal insufficiency. Arch Intern Med 1965;115:418-20.

${ }^{8}$ Fiddick J, Oleesky S. Hyperpotassaemic paralysis. Lancet 1953;ii: 343-44.

' Bull GM, Carter AB, Lowe KG. Hyperpotassaemic paralysis. Lancet 1953;ii:60-3.

10 Troni W, Luda E. Electromyographic study on experimental hyperkalemia. Acta Neurol (Napoli) 1978;33:381-407.

"Engel AG. Metabolic and endocrine myopathies. In: Walton JN, ed. Disorders of Voluntary Muscle. 4th ed. Edinburgh: Churchill Livingstone, 1981:669.

12 Engel AG. Hypokalemic and hyperkalemic periodic paralysis. In: Goldensohn ES, Appel SH, eds. Scientific Approaches to Clinical Neurology. Philadelphia: Lea \& Febiger. 1977; 2:1746.

13 Vilchez JJ, Cabello A, Benedito J, Villarroya T. Hyperkalemic paralysis, neuropathy and persistent motor neuron discharges at rest in Addinson's disease. $J$ Neurol Neurosurg Psychiatry 1980;43:818-22. 